\title{
Impact of Pandemic on Online Marketplace Active Users
}

\author{
Primagita Fridhayanti*, Nurafni Eltivia, Nur Indah Riwajanti \\ Department of Accounting \\ Malang State Polytechnic \\ Malang, Indonesia \\ *pfridhayanti@gmail.com
}

\begin{abstract}
This study aims to determine the Shopee Online Marketplace Active Users forecasting against the Covid-19 pandemic in 2021-2022. This study uses secondary data from the iPrice website with 11 years of data from the 2018-2020 period to support this objective. This research is a descriptive quantitative research using secondary moving average forecasting with time series. This study's results indicate that the second quarter of 2021 and the second quarter of 2022 will significantly increase online marketplace active users. It will be better if Shopee can make a promotion every month so that there is a promo every month so that the graph of the increase is stable. The result of this research, it is hoped that it can help the Indonesian economy amid the Covid-19 pandemic.
\end{abstract}

Keywords-Covid-19, forecasting, moving average, online marketplace

\section{INTRODUCTION}

Currently, Indonesia is being hit by the Covid-19 pandemic, which has affected individuals, households, companies, and even the economy of a country to global coverage. The spread of the Covid-19 virus from human to human is the primary source of transmission so that it become widespread. Along with the development of information technology, as stated above, the product of the world of information and communication technology is increasingly intensive, making people look for solutions to meet their daily needs amid the Covid-19 pandemic. With the social distancing policy, many schools and companies implement work from home, school from home, and online learning.

Taufik and Ayuningtyas' research [1] aims to find the impact of the Covid-19 pandemic on online platform-based business activities in Jakarta. The research used descriptive qualitative methods and data from January to mid-April 2020. Documentation was used to collect the data. It is found that the impact of the Covid-19 pandemic was classified as three business activity stages, first on sustained or stable business, second in declining, and thirdly on developing businesses. So it is necessary to have further research with a complete research scope.
On $11^{\text {th }}$ February 2020, the World Health Organization (WHO) announced the name of the disease as Corona Virus (Covid-19), which caused by the SARS-CoV-2 virus, previously known as 2019-nCoV, and declared as a pandemic on March 12, 2020 [2]. The increasing number of Covid-19 virus transmission in Indonesia has made the government issue a policy to maintain social distancing or what is often called social distancing. Social distancing means reducing activities outside the home and interacting with other people directly [3]. Due to this, people are also looking for other means to fulfill their daily necessities, one of them is by online shopping.

E-commerce is a process that enables internet-based technology to facilitates trade in the form of an application with the Consumer to Consumer (C2C) method. E-commerce services are increasing and emerging along with a vast market share; with a social distancing policy, online shopping platforms are competing to be in the forefront. Competition among e-commerce service providers is indirectly tighter to get their customers [4]. In a narrow sense, e-commerce refers to various online commercial activities that focus on exchanging commodities with electronic methods, especially computer networks, by companies, factories, industry players, and consumers [5].

Nowadays, millennials are very accustomed and not only can't be separated from the digital world but also develop increasingly sophisticated technologies such as the advancement of the internet, the presence of smartphones, and social media. Due to Covid-19 pandemic, e-commerce growth has increased significantly. Long before the pandemic, public interest in e-commerce could attract consumer and contribute to the Indonesian economy. Another government policy is the Large-Scale Social Restrictions (PSBB), which ultimately must be implemented in all regions in Indonesia. There has been a reduction in several business activities in trade centers, offices, educational activities, tourism, etc. Based on data obtained from iPrice, it shows that from the first quarter of 2018 to the second quarter of 2019, Shopee's e-commerce raised to number one based on the Playstore ranking.

Various methods are featured to attract customers, such as cashback promos, free shipping to pay later is provided by 
Shopee as an advantage for users who have the online platform application [6]. One of the things that distinguish Shopee from other e-commerce applications is Shopee offers a "Shopee Warranty." The seller does not deliver the goods, the goods' stock is exhausted, or the goods are not in good condition, the buyer can apply for a refund through Shopee so that the paid funds can be returned to the customer's bank account within a maximum of $2 \times 24$ hours. By realizing the convenience of shopping amid the Covid-19 virus situation and efforts to deal with the New Normal transition condition, as has recently been implemented in almost all parts of Indonesia so that's why many people have an account at online marketplace to get their daily goods. With prices that are quite affordable, people don't need to leave the house to get the items they want, just through e-commerce, so people only need to wait at home until the purchased items arrive home. Due to this convenience, there is an increasing number of Shopee platform applications from before the Covid-19 pandemic to the present. Due to this, people are also looking for other means to fulfill their daily necessities, one of them is by online shopping.

The definition of forecasting is interpretation. Forecasting is the art or science to predict future events [7]. The forecasting method uses time series analysis as the primary variable by relying on historical data. The calculation can be done by using the moving average method to determine the projection of the forecasting results. According to Makridakis [8], the prediction predicts variable values based on the known values of these variables or related variables. According to Heizer \& Render [9], forecasting is a basic input in operations management's decision-making process because forecasting provides information on future demand. The forecast predicts what will happen, but it is not certain that the company can implement it [10].

This study aims to determine active users' prediction amid the Covid-19 pandemic based on data from 2018-2020 for the 2021-2022 projection using e-commerce active user objects through social media. The analytical method uses the moving average forecasting method, which is calculated through the time series trend [11].

\section{RESEARCH METHODS}

This study uses a quantitative approach and forecasting method to determine the trends that occur in the future on the number of active users of the Shopee application amid the Covid-19 pandemic. This study uses secondary data obtained from the iPrice website and the internet site. In this study, the variables used are active users of the Shopee application-login into application. The data in this study uses quarterly data from 2018 to 2020 so that it is expected to be able to predict the forecast for the period 2021 and 2022 on the Shopee application amid the Covid-19 pandemic.

The analysis method used is Time Series Analysis and Moving Average based on the previous year's historical data, predictions can be made for the next year using the forecasting method. Microsoft Excel is used to generate forecast form the calculated trend based on historical data [12]. Moving Average (Moving Average) is a method of forecasting that is done by taking a group of observed values, then calculating it for the average value as a forecast for the coming period [13].

$$
\begin{aligned}
M t & =F t+1 \ldots \ldots \ldots \ldots \ldots \ldots \ldots \ldots \ldots \ldots \ldots \\
& =\frac{Y t+Y t-1+Y t-2+\ldots+Y t-n+1}{n} \ldots \ldots . .
\end{aligned}
$$

$\mathrm{Mt}=$ Moving Average for period $\mathrm{t}$

$\mathrm{Ft}+1=$ Forecast for the period $\mathrm{t}+1$

$\mathrm{Yt}=$ real value for period $\mathrm{t}$

$\mathrm{n}=$ The number of limits in the moving average

\section{RESULTS AND DISCUSSION}

Active user data collection that is processed from the fourth quarter of 2018 to the third quarter of 2020 is obtained from iPrice and internet sites with 11 data. Shopee application user data can be seen in the table below:

TABLE I. DATA ON THE NuMBER OF SHOPEE ONLine MARKETPLACE USERS

\begin{tabular}{|l|l|l|l|}
\hline No. & Year & \multicolumn{1}{c|}{ Quarter } & Account \\
\hline 1 & 2018 & 1 & $34,510,600$ \\
\hline 2 & & 2 & $55,964,700$ \\
\hline 3 & & 3 & $44,400,525$ \\
\hline 4 & & 4 & $67,677,900$ \\
\hline 5 & 2019 & 1 & $74,995,300$ \\
\hline 6 & & 2 & $90,705,300$ \\
\hline 7 & & 3 & $57,445,890$ \\
\hline 8 & & 4 & $72,973,300$ \\
\hline 9 & 2020 & 1 & $71,533,300$ \\
\hline 10 & & 2 & $93,440,300$ \\
\hline 11 & & 3 & $96,532,300$ \\
\hline
\end{tabular}

Source: iPrice, 2020

Based on table I, a graph is created that shows a fluctuating picture of Shopee's online marketplace users. In Table 1, it is known that at the end of 2018 to early 2019, there was an increase, namely at 90,705,300 and a very sharp decline occurred in the third quarter of 2019. This significant decrease was caused by the Covid-19 pandemic.

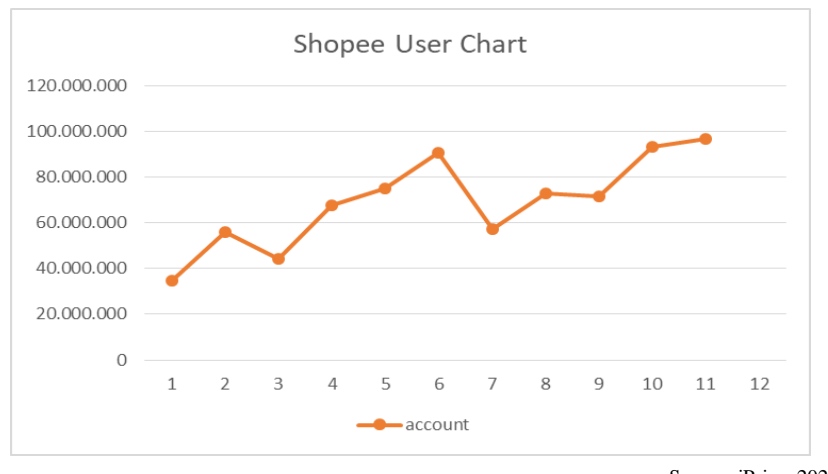

Fig. 1. Shopee's online marketplace user graph.

Based on figure 1 above, forecasting calculations are carried out using the moving average method with Microsoft Excel. Shopee online marketplace users in the first quarter of 2020 experienced a steady increase until the third quarter of 
2020. Table 2 shows the result forecasting based on data obtained with the help of Microsoft Excel for the projections for the period 2021-2022. Active user data were very volatile in 2018. Furthermore, the data will be used for projection using the moving average method, analyzing forecasts for the year 2021-2022.

TABLE II. ForeCASTING ACTIVE USERS ONLINE SHOPEE MARKETPLACE

\begin{tabular}{|l|l|l|l|l|}
\hline No. & Year & Quarter & \multicolumn{1}{|c|}{ Account } & \multicolumn{1}{|c|}{ Forecast } \\
\hline 1 & 2018 & 1 & $34,510,600$ & 45867767.16 \\
\hline 2 & & 2 & $55,964,700$ & 59721859.11 \\
\hline 3 & & 3 & $44,400,525$ & 43544838.8 \\
\hline 4 & & 4 & $67,677,900$ & 59886335.07 \\
\hline 5 & 2019 & 1 & $74,995,300$ & 63682390.32 \\
\hline 6 & & 2 & $90,705,300$ & 80864393.48 \\
\hline 7 & & 3 & $57,445,890$ & 57707025,53 \\
\hline 8 & & 4 & $72,973,300$ & 77898749.14 \\
\hline 9 & 2020 & 1 & $71,533,300$ & 81497013.47 \\
\hline 10 & & 2 & $93,440,300$ & 102006927.8 \\
\hline 11 & & 3 & $96,532,300$ & 71869212,26 \\
\hline 12 & & 4 & & 95911163,21 \\
\hline 13 & 2021 & 1 & & 99311636.62 \\
\hline 14 & & 2 & & 123149462,2 \\
\hline 15 & & 3 & & 86031398.99 \\
\hline 16 & & 4 & & 113923577.3 \\
\hline 17 & 2022 & 1 & & 117126259.8 \\
\hline 18 & & 2 & & 144291996,6 \\
\hline 19 & & 3 & & 131935991.4 \\
\hline 20 & & 4 & & \\
\hline
\end{tabular}

Source: Data Processed, 2020

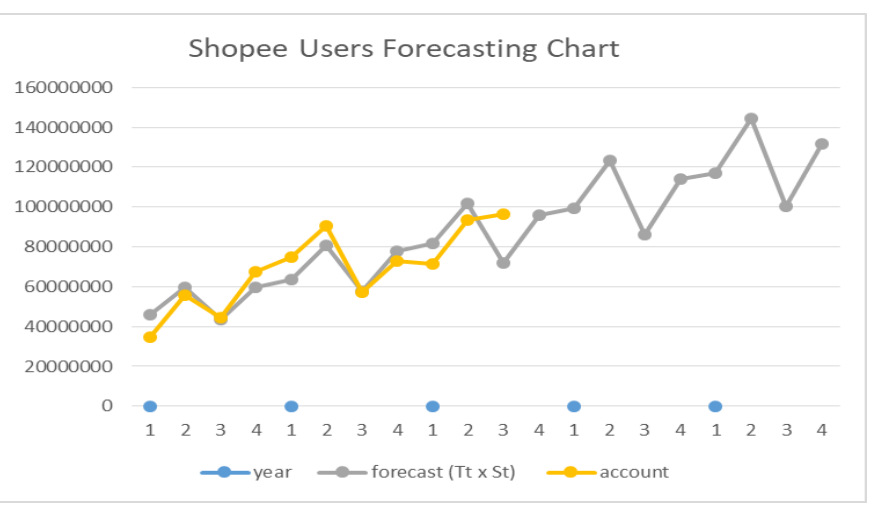

Source: Data processed, 2020

Fig. 2. User forecasting chart (2021-2022).

Based on table 2 and figure 2, it can be seen that the prediction of active users of the Shopee online marketplace in 2021-2022 is $144,291,997$ users, with a peak occurring on the third quarter of 2022. The number of users on the third quarter of 2022 is higher than on the second quarter of 2021, $123,149,463$ users. When viewed as a whole, there was an increase on the second quarter of 2020; this occurred on April to June, at which time the government issued a PSBB policy so that people were encouraged to shop from home; this caused a surge of inactive users on the Shopee online marketplace to reach a value of 93,440,300. After that, there was a decline in active Shopee users in the third quarter of the same year; this was due to the New Normal policy, which resulted in a decline in Shopee users in that quarter. At table 2, on the second quarter of 2022, the projected value of Shopee users reached $144,291,997$ compared to the number of active Shopee users in the fourth quarter of 2022, which was $131,935,991$. The second quarter in 2021 and the second quarter of 2022 will experience a significant increase. This is due to the Big Ramadhan promo held by Shopee, which greatly affects the high number of active Shopee users in that quarter. There is an increase and decrease in Shopee users that can be seen through the graph due to the promos imposed by Shopee; of course, this also affects the big days that exist every month. The second quarter in 2021 and the second quarter of 2022 will experience a significant increase; this is due to the Big Ramadhan promo held by Shopee, which greatly affects the high number of active Shopee users in that quarter. There is an increase and decrease in Shopee users that can be seen through the graph due to the promos imposed by Shopee; of course, this also affects the big days that exist every month.

\section{CONCLUSIONS AND SUGGESTIONS}

The results of this study indicate that there is a predictable increase in the frequency in the second quarter of 2021 and the second quarter of 2022. This is due to holidays such as Idul Fitri in the second quarter of 2021 and the second quarter of 2022, namely in May. This is evidenced by the high frequency of active Shopee Online Marketplace users. From the results of the above research, it is hoped that it can help the Indonesian economy amid the Covid-19 pandemic. The limitation of this study is that it only uses data in a fairly short period of time. It needs to be further investigated with a complete research design and scope and a longer forecasting period. For further research, researchers comparing other online marketplaces such as Lazada, Tokopedia, Bukalapak, etc., with sales transaction variables with forecasting for a long time.

\section{REFERENCES}

[1] Taufik and E.A. Ayuningtyas, "The Impact of the Covid-19 Pandemic on Business and the Existence of Online Platforms," Journal of Entrepreneurial Development, vol. 22, no. 01, pp. 21-32, 2020.

[2] A. Susilo, C.M. Rumende, C.W. Pitoyo, W.D. Santoso, M. Yulianti, r. Sinto, and E. Yunihastuti, "Coronavirus Disease 2019: A Review of Recent Literature," Indonesian Journal of Internal Medicine, vol. 7, no. 1, pp. 45-67, 2020.

[3] S. Papdi and K. Ke, "The readiness of the Ministry of Health in Facing the Outbreak of Novel Coronavirus (2019-NCov)," Directorate General of Disease Prevention and Control, Ministry of Health, pp. 1-26, 2020.

[4] P. Felita and E. Oktivera, "The Influence of Shopee Indonesia's Sales Promotion on Consumer Impulsive Buying. Case Study: Impulsive Buying on STIKS Tarakanita Students," Journal of Communication and Business Sciences, vol. 4, no. 2, pp. 159- 185, 2019.

[5] Z. Qin, Introduction to E-commerce. Berlin: Springer, Thing, p. 121, 2009.

[6] K-hyee, "Review Belanja: Plus Minus Belanja Di Shopee," [online]. Retrieved from https://k-hyee.blogspot.com/2017/11/review-belanjaplus-minus-belanja-di.html

[7] F.I. Rahmawati, N. Eltivia, and K.D.S. Susilowati, "Forecasting the Arrival of Indonesian International Tourists: Holt's Winter Exponential Smoothing Method," Mahardhika Media Journal, vol. 18, no. 2, pp. 233$240,2019$.

[8] S. Makridakis, S.C. Wheeleright, and V.E. McGee, Forecasting Methods and Applications. Padang: Erlangga. Thing, p. 519, 1988. 
[9] J. Heizer and B. Render, Operations Management Sustainability and Supply Chain Management Eleventh Edition. United States: Pearson Education, Inc. Thing. 136, 2011.

[10] A. Mustofa, N. Eltivia, and Z.A. Haris, "Contribution of Polytechnic New Student Admissions Forecasting: As an Income Estimating Tool," Mahardhika Media Journal, vol. 18, no. 2, pp. 266-276, 2019.

[11] I.L.P. Navalina, N.I. Riwajanti, S. Sulistyono, and L. Djajanto, "Forecasting of Marine Fishery Production Sold at TPI (Tons) Using the
Single Exponential Smoothing Method," Mahardhika Media Journal, vol. 18, no. 2, pp. 206-214, 2019.

[12] N. Sulthan, N. Eltivia, and N.I. Riwajanti, "Implementation of the Exponential Smoothing Method for Forecasting the Arrival of International Tourists on the Island of Bali," Mahardhika Media Journal, vol. 18, no. 2, pp. 171-178, 2020.

[13] P. Subagyo, Forecasting Concepts and Applications. Yogyakarta: BPFE. Thing. 101, 2008. 